\title{
Student Teachers Competence in Curriculum Development - A Case in Czech Universities
}

\section{LIU Li, Jana Poláchová Vašt’atková}

\begin{abstract}
The purpose of this study is to explore what student teachers in general, English as a foreign language (EFL) student teachers in particular, competence in curriculum development is like in the current Czech context. Using the questionnaire survey, the authors investigated student teachers' knowledge and skills about using curriculum materials and implementation of a lesson. Findings indicate that student teachers to a large extent have positive attitudes to specific needs of learning English, followed by different resources, language teachers' different roles, and contexts during uses of curriculum materials. With regard to the implementation of a lesson, student teachers are more confident in using a lesson plan followed by the classroom management than in lesson planning followed by evaluation. The results also indicate that student teachers' pedagogical content knowledge and curriculum knowledge need to be further supported.
\end{abstract}

Key words: curriculum development, curriculum materials, curriculum implementation, teacher competence, student teacher, Foreign language teaching 


\section{Introduction}

Research focusing on Czech novice teachers has pointed out that they experience problems during a period of novice-teacher professional adaption, such as lack of pedagogical skills, difficulties with the relationship with pupils and their parents and other teachers, etc. (Černochová, 2009). Some novice teachers do not perceive practicing teachers as flexible users of curriculum materials, viewing curriculum design as an inauthentic teaching task (Beyer \& Davis, 2012). The growth in the pedagogical autonomy of Czech schools has brought increased demands on teachers' professionalism who has become the creators of school curriculum (Seberová, 2010). Each individual school has to develop its own School Education Programme based on the Framework Educational Programme for Basic Education (FEP BE). For a successful implementation, the organizational and practical considerations associated with curriculum development need to be taken into consideration. Nevertheless for some educational professionals, curricular development may be too hefty a burden. Lack of teaching aids and further necessary training to take on this new responsibility can often be seen (Green, 2008). Even though student teachers are often faced with situations in the classroom which cannot be planned or foreseen, too little assistance is provided for pupils to build up their professional knowledge and competence required for successful teaching practice (Mehlmauer-Larcher, 2012, p. 175), such as pedagogical content knowledge (Shulman, 1987), pedagogical design capacity (Brown, 2002), etc. The purpose of this study is to explore what student teachers ${ }^{1}$ in general, EFL student teachers in particular, competence in curriculum development is like in the context of the Czech Republic.

\section{Teacher competence in curriculum development}

The concept of competence ${ }^{2}$ dominated the management strategy literature of the 1990s, which emphasized "core competence" as a key organizational resource that could be exploited to gain competitive advantage (e.g. Campbell \& Sommers Luchs, 1997). EU priorities for improving Teacher Quality and Teacher Education, as defined in the Conclusions of the Education Councils of November 2007, 2008 and 2009, recall the need to improve teacher competencies, as well as to promote professional values and attitudes, mentioning as examples the following teacher requirements (Council of the European Union, 2007, 2008, 2009):

\footnotetext{
I In this study, the prospective teachers are referred to as "student teachers"; the learners in the school classroom as "pupils".

2 According to Delamare-Le Deist and Winterton's (2005) research, "competence" generally refers to functional areas and "competency" to behavioural areas but usage is inconsistent. Besides, teacher capacities and teacher competences are used sometimes as synonyms (Francesca, 2011).
} 
- a specialist knowledge of subjects

- pedagogical skills, comprising the following: teach heterogeneous classes; use ICT; teach transversal competences; create safe attractive schools

- cultures/ attitudes of reflective practice, research, innovation, collaboration, autonomous learning.

International scholarly consensus seems to converge on the concept of competences as basic requirements for teaching reflects increasing academic and policy interest (Francesca, 2011), which are articulated in knowledge, craft skills and dispositions (Feiman-Nemser, 2001), focusing the attention on the social responsibilities of teachers. Dispositions include beliefs, attitudes, values and commitment, focused on action. Generally, the term "competence" is increasingly used in a comprehensive way, as a dynamic dimension which goes beyond the original scientific connotations of containing and absorbing quantities. It focuses on the potentialities of continuous development and achievement, associated with aims and objectives in a lifelong learning perspective. The competence, as it is repeatedly suggested in relevant literature, should be viewed as a holistic concept - the dynamic combination of knowledge, understanding and skills (Francesca, 2011). Therefore, this study uses the term competence to highlight the dynamic and conative perspectives. It represents the knowledge and skills acquired through college/university based teacher programmes (Moreno, 2005), and indicates what student teachers know and can do (Moreno, 2005, p. 146) rather than "what teachers have".

The curriculum development is a generic concept which includes policy, design, implementation, technology, supervision, and evaluation (Pinar, Reynolds, \& Slattery, 1995). Pinar et al. (1995) borrowing viewpoint form Decker Walker (1979), say that: the one term "curriculum development" covers at least three distinguishable enterprises: curriculum policymaking, the establishment of limits, criteria, guidelines, and the like with curricula must comply, without developing actual plans and material for use by students and teachers; generic curriculum development, the preparation of curriculum plans and material for use potentially by any students or teachers of a given description; and site-specific curriculum development, the many measures taken in a particular school or district to bring about curriculum change there. (Decker Walker, 1979, p. 269, as cited in Pinar et al., 1995. p. 665)

It is clear that three areas on curriculum development is identified by Walker (1979): curriculum policy, curriculum planning and design (generic curriculum development), and curriculum implementation (site specific curriculum development).

In the research on curriculum implementation, Snyder, Bolin, and Zumwalt (1992) list three major approaches: (a) the fidelity approach which confines curriculum to "a course of study, a textbook series, a guide [and] a set of teacher plans", (b) the mutual- 
adaptation approach which regards curriculum implementation as a "process whereby adjustments in a curriculum are made by curriculum developers and those who use it in the school or classroom context" (Snyder et al., 1992, p. 410), and (c) the enactment approach which sets curriculum as a process "jointly created and jointly and individually experienced by pupils and teacher" (ibid., p. 428). According to Shawer's (2003) point of view, the mutual-adaptation approach and the enactment approach are considered two forms of classroom-level curriculum development. The adaptation approach leads teachers to become curriculum-developers who use various sources in addition to curriculum materials through curriculum adjustments. Teachers adapt existing materials and topics, add new topics, leave out irrelevant elements, use flexible lesson plans, respond to student differences and use various teaching techniques. Through this interaction, teachers turn curriculum from the institutional into the pedagogical level (experienced/enacted curriculum) (Doyle, 1992). Curriculum experts translate skills, knowledge, concepts and values into curriculum materials, whilst, teachers develop the second version by using curriculum materials (Ben-Peretz, 1990; Remillard, 1999). The enactment approach which leads teacher's role ranging from using, adapting and supplementing external curriculum to curriculum-making represents another form of classroom-level curriculum development (Shawer, 2003). The teachers have become curriculum-makers who assess pupils' needs to derive curriculum themes, use strategies of curriculum-planning, curriculum-design, material-writing and curriculum-free topics. In addition, they improvise and develop and use their pedagogic techniques.

The curriculum development as a process may occur in various areas of the curriculum, ranging from national and regional levels to schools and classrooms. At the micro level, teachers are involved in the process of curriculum development allowing individual pupils' needs to be met and promoting continuous improvement in practice, function as "user-developers" (Connelly, 1972) and "grass-root developers" (Ben-Peretz, 1980), etc. rather than just complying with imposed standards (Darling-Hammond et al., 2005). As Kirk and Macdonald (2001) claim, "teachers' authoritative voice is rooted in the local context of implementation ..." (p. 565) which means that teachers' contributions are particularly important in respect of the local context, namely, the classroom or school.

\subsection{Framework of student teachers competence in curriculum development}

Based on the literature review of the existing knowledge base, which means reviewing the relevant studies about curriculum development, teacher's role in curriculum development and practicing teacher competences/knowledge, a framework of understanding student teacher competence in curriculum development was identified in this study (See Figure 1). 


\section{Figure 1}

Framework of Student Teacher Competence in Curriculum Development

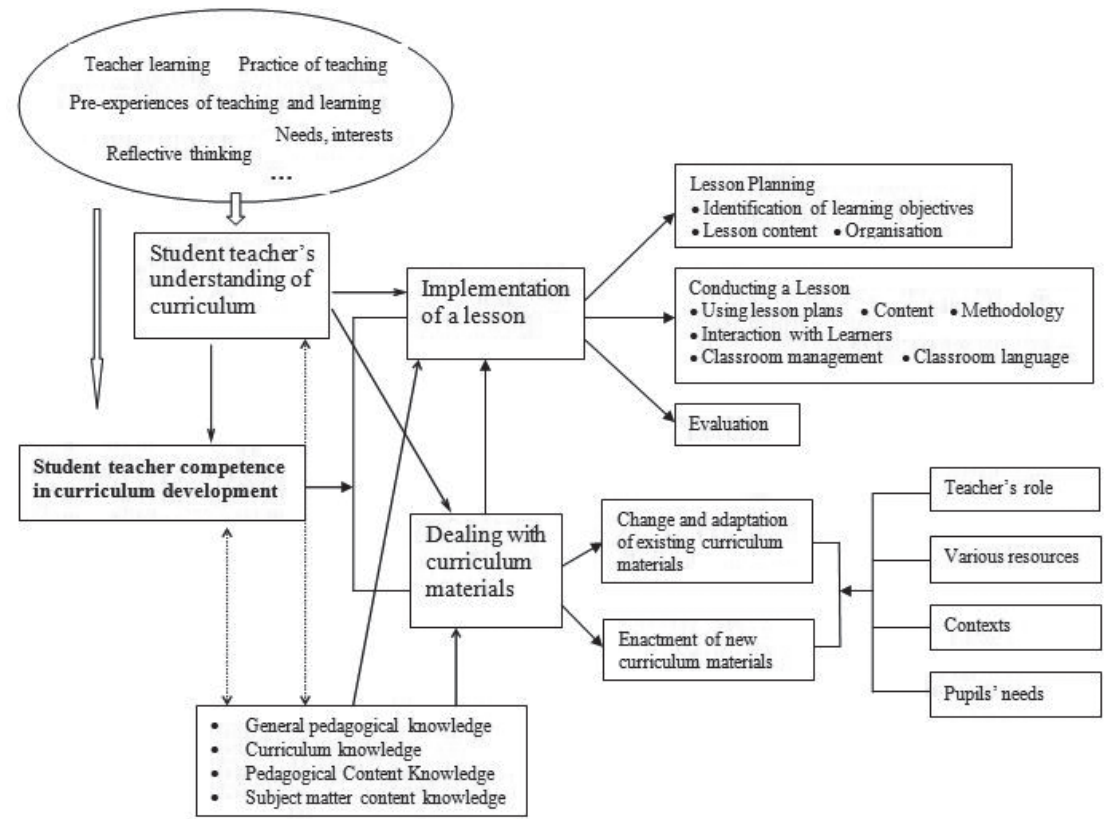

The scope and nature of teacher involvement with curriculum development varies from one curriculum area to the next (Carl, 2005). In this study, student teachers competence in curriculum development represents their knowledge and skills which acquired through university based teacher programmes about use of curriculum materials to implement a curriculum. As it shown in figure 1, student teacher competence in curriculum development in this framework is a construct which includes student teacher's competence to deal with curriculum materials as well as his/her competence to implement a curriculum during the process of teaching. In other words, this competence as a series of capabilities is expressed during the practice. In fact, teachers' use of curriculum materials and implementation of a curriculum are interactive activities in the process of their daily practice. The approaches of teachers to implement a curriculum depend on how they use curriculum materials (Shawer, 2010). Curriculum materials include lesson plans, teacher guides, textbooks, worksheets, etc. The use of curriculum materials involves the practices including the reduction, addition or adaptation of existing materials and enactment of new materials which based on the specific pupils' needs, contextual circumstances, and local goals and standards (Brown, 2009) as well 
as student teachers' perception of various resources and teacher's role. Regarding implementation of a curriculum is a continuous activity which includes lesson planning, conducting a lesson, and evaluation. In addition, student teachers' understanding of curriculum may impact his/her comprehension of the curriculum intent (aims, goals and learning objectives), content, teaching strategies and instructional assessment (Cheung \&Wong, 2002). That is to say, it influences the process of his/her use of curriculum materials and implementation of a curriculum. Moreover, student teacher competence in curriculum development is not a static, but rather a continuous and changing formation, integrating general pedagogical knowledge, pedagogical content knowledge, subject knowledge and curriculum knowledge, in Shulman's (1987) term. It evolves over time and across contexts along the teacher professional continue (Feiman-Nemser, 2001).

\section{Research design and findings}

This study aims to explore what Czech student teachers competence in curriculum development is like. To be more concrete, it can be described into two questions: a) what knowledge and skills do student teachers have about uses of curriculum materials, and b) what knowledge and skills do student teachers have about implementation of a lesson?

The research sample consisted of sixty one EFL student teachers, 11 males and 50 females, who were in the second year of two-year follow-up master's study programmes for preservice English teacher preparation at Palacky University in Olomouc, Masaryk University in Brno and Charles University. The questionnaire survey was conducted during the winter semester of academic year 2013/2014, after student teachers finished their one-month teaching practice at primary and secondary schools. Almost all the EFL student teachers at English department at the three universities participated in the survey; however the survey was on a voluntary basis. $18.0 \%$ of the student teachers were male while female student teachers were $82.0 \%$, with the average age was 25 years old, five of them were more than thirty.

The survey instrument used for this study was developed based on established procedures in literature, especially inspired by the European Portfolio for Student Teachers of Languages- A reflection tool for language teacher education (Council of Europe, 2007). Actually, it could be seen as an adapted version of the EPOSTL. The questionnaire consisted of seven sections with 73-item. Section one contained demographic data. Section two concerned student teachers' understanding of curriculum. Sections three to six concerned student teachers competence towards various resources, contexts, pupils' needs and implementation of a lesson. Section seven was about student teacher's selfreflection of language teacher's role. A 5-point Likert scale was introduced in the main 
body of questionnaire. Responses on the items ranged from: " 1 = strongly disagree", " 2 = disagree", " $3=$ neutral", " $4=$ agree" and " $5=$ strongly agree".

A panel of experts from curriculum and pedagogy and subject matter reviewed the questionnaire to determine its content and face validity. Moreover, one EFL teacher and one EFL student teacher were selected to conduct the field test in order to help clarify items. After then, a draft instrument was developed for the pilot test. Cronbach's alpha was applied to the data from the pilot study to establish a coefficient of internal consistency. The internal consistency reliability coefficient for the sections 2, 3, 4, 5, 6 and 7 was $0.70,0.89,0.87,0.75,0.91$ and 0.88 .

\subsection{What knowledge and skills do student teachers have about uses of curriculum materials?}

Curriculum materials are intimately connected to teachers' daily work, playing a vital role in how new ideas about teaching and learning find life or fail in classrooms. As discussed above, student teachers' uses of curriculum materials will be impacted by various resources, pupils' needs, contexts (including external requirements/ standards) and language teacher's role, therefore, this question is analyzed by synthesis of the results of these dimensions, as follows.

Survey results indicated that half of the respondents had positive position on all the items related to the resources in language teaching practice. $93.4 \%$ of the respondents agreed or strongly agreed with the item that represented the knowledge and skills of making use of ideas and materials included in teachers' handbooks and resource books. Over $88 \%$ agreed or strongly agreed with items which reflected the knowledge and skills of selecting texts and language activities from course books and designing learning materials and activities based on particular pupils. Regarding other items related to specific pupils' needs, interests and language level, $73.8 \%$ agreed or strongly agreed with that they could identify a range of course books /materials, however, $42.6 \%$ were neutral or disagreed with that they could recommend appropriate books to particular pupils. Moreover, over $78 \%$ agreed or strongly agreed with items which represented the knowledge and skills of using ICT and selecting materials to promote pupils'language skills of listening, reading and speaking. The results also indicated that the respondents were more competent in selecting materials to stimulate speaking activities.

Student teachers' responses to the statements towards the contexts are shown in table 1 below. Over $65 \%$ of the respondents agreed or strongly agreed with items 23,24 and 25 , which reflected that they could teach language within social and cultural contexts as well as create a supportive atmosphere to stimulate pupils' speaking. $55.7 \%$ agreed or strongly agreed with item 22 which represented their knowledge and skills of adapting teaching according to "the recognition of the organisational constraints and resource limitations" of school, whilst $6.6 \%$ disagreed and $37.7 \%$ were neutral about it. 
Although a total of $54.2 \%$ indicated that they understood "the requirements set in the FEP BE" (item 20), only $27.9 \%$ indicated that they could design language courses around the requirements set in the FEP BE (item 21), more than $55 \%$ were neutral about it.

Table 1

Student Teachers and Context

\begin{tabular}{|l|c|c|c|c|c|c|c|}
\hline $\begin{array}{l}\text { Questionnaire Section IV } \\
\text { Towards the Contexts }\end{array}$ & $\begin{array}{c}\text { Strongly } \\
\text { Agree }\end{array}$ & Agree & Neutral & Disagree & $\begin{array}{c}\text { Strongly } \\
\text { Disagree }\end{array}$ & \multicolumn{2}{|c|}{$\mathrm{N}=61$} \\
\hline $\begin{array}{l}\text { 20. I can understand the requirements set } \\
\text { in the FEP BE (Framework Educational } \\
\text { Programme for Basic Education). }\end{array}$ & 6.6 & 47.6 & 31.1 & 13.1 & 1.6 & 3.44 & 0.87 \\
\hline $\begin{array}{l}\text { 21. I can design language courses around } \\
\text { the requirements of the FEP BE. }\end{array}$ & & 27.9 & 55.7 & 13.1 & 3.3 & 3.08 & 0.74 \\
\hline $\begin{array}{l}\text { 22. I can adapt my teaching according } \\
\text { to the recognition of the organisational } \\
\text { constraints and resource limitations existent } \\
\text { at my school. }\end{array}$ & 3.3 & 52.4 & 37.7 & 6.6 & & 3.52 & 0.67 \\
\hline $\begin{array}{l}\text { 23. I can relate what I teach to current events } \\
\text { in local and international contexts. }\end{array}$ & 19.7 & 49.2 & 22.9 & 8.2 & & 3.80 & 0.86 \\
\hline $\begin{array}{l}\text { 24. I can relate the language I am teaching } \\
\text { to the culture of those who speak it. }\end{array}$ & 11.5 & 60.6 & 21.3 & 6.6 & & 3.77 & 0.74 \\
\hline $\begin{array}{l}\text { 25. I can create a supportive atmosphere } \\
\text { that invites learners to take part } \\
\text { in speaking activities. }\end{array}$ & 37.7 & 34.4 & 24.6 & 3.3 & & 4.07 & 0.87 \\
\hline
\end{tabular}

Note: Bold italics indicate that the percentages of neutral and disagreement were together over $50 \%$.

As for student teachers' responses to the statements towards specific needs of learning English, an overwhelming opinion that the student teachers "understand the personal, intellectual and cultural value of learning English" becomes apparent. As for dealing with different motivations and pupils' affective needs in English teaching and learning, over $75 \%$ of the respondents agreed or strongly agreed with the statements. Whilst, $64 \%$ agreed with that they could think about pupils' cognitive needs.

Language teachers have a number of roles to play. Besides teaching subjects, they may need to promote the value of language learning to pupils (Newby et al., 2007). Altogether $80.3 \%$ of the student teachers reported that they could promote the value and benefits of English learning to pupils. $44.3 \%$ respondents indicated that they could use the theories to guide teaching, and $37.7 \%$ indicated that they could identify specific pedagogical/ didactic issues related to the pupils of teaching in the form of action research.

In accordance with the analysis above, it seems that most student teachers have positive attitudes about taking into account specific needs of learning English, differ- 
ent resources, language teachers' different roles, and contexts during uses of curriculum materials, such as, pupils' language level, motivations and cognitive and affective needs, values of learning English, and social and cultural teaching contexts, etc. Previous research indicates that some teachers make productive changes to curriculum materials that support and enhance the intent of the materials while other teachers' selection and enactment of materials can and do vary in ways that can limit their efficacy (McNeill \& Pimentel, 2010), even to fit their classroom contexts, may diverge from developers' intentions for materials (McNeill, 2009). In fact, teachers' uses of curriculum materials indicate their ability to mobilize personal resources (i.e., knowledge, belief, identities and orientations) as well as resources embedded in the materials themselves to make pedagogical decisions that accomplish particular instructional goals in light of affordances and constraints of their professional contexts (Brown, 2002). But in this study, only slightly over than $50 \%$ of student teachers indicated that they could adapt teaching based specific contextual constraints, and less than $30 \%$ indicated that they could design language courses around the requirements set in the FEP BE. As for other statements related to the use of pedagogical knowledge, more than $30 \%$ were neutral. Even for the understanding of the requirements set in the FEP BE, less than $55 \%$ of student teachers indicated that they could understand.

\subsection{What knowledge and skills do student teachers have about implementation of a lesson?}

Implementation of a lesson is a continuous activity. For the teacher the most important is to know why he/she makes a decision on which material to bring into the classroom and which activities to choose (Newby et al., 2007, p. 33). The decision is dependent on curriculum requirements and on specific groups of pupils. Teachers need to know how to transform aspects of the curriculum into transparent aims and objectives which can be understood by the pupils as well as need to take into account individuals' characteristics and their prior learning to sequence activities in a coherent yet flexible way in class. Besides, in primary and secondary classroom, teachers are faced with issues that render the control of classroom challenging every day. Within the context of foreign language teaching and learning, it would be an error to over-generalize foreign language teachers' challenges with classroom management in an effort to introduce possible solutions without first considering the uniqueness of this particular teaching and learning environment (Evans, 2012). As indicated by previous research (Borg, 2006), one of the distinctive characteristics of language teaching and learning is the teaching methodology which focuses on how teachers can deal with the four main skills of speaking, writing, listening and reading and support aspects of language learning, such as grammar, vocabulary, pronunciation and written and oral communication. Furthermore, evaluation is one of core tasks of teachers by its very nature. Only if teachers 
are able precisely to diagnose the pupils' learning process and adjust their teaching methods to the results of the assessments with a specific effort to consider the pupils' heterogeneity, instruction leads to higher student achievement. Figure 2 is a representation of the responses to these issues. Results showed that means for most statements were above 3.7 which indicated that most of respondents were competent in that. To be more concrete, respondents' reactions are discussed respectively as follows.

Figure 2

Student Teachers' Competence in Implementation of a Lesson

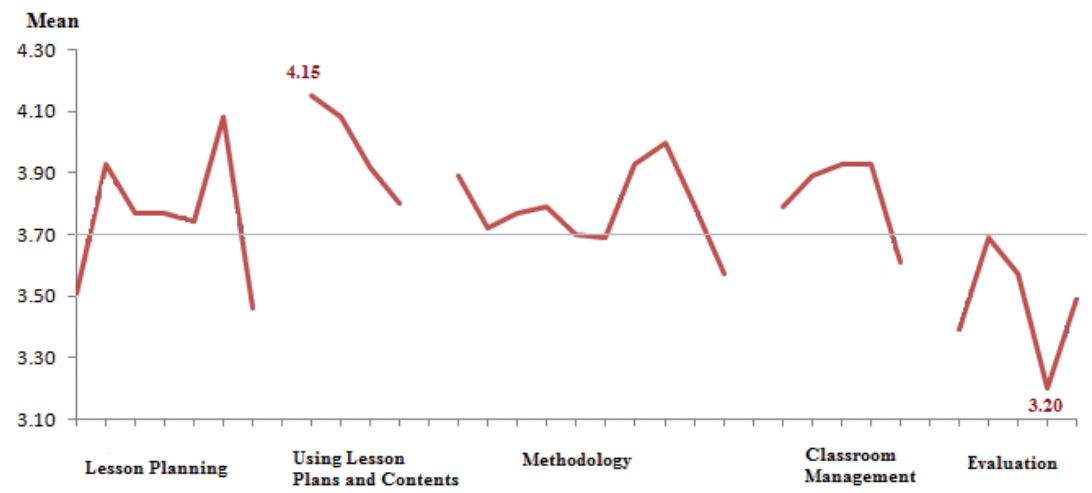

The results in table 2 below are on student teachers' knowledge and skills about lesson planning. The first three items are about identification of learning objectives, the last are about planning and selecting activities and content. Results showed that that over $60 \%$ of them indicated competencies in planning activities, especially to "link grammar and vocabulary with communication" (the agreement of item 36 was $88.5 \%$ ), then to emphasise the interdependence of the four language skills (item 34, 64\%) and of "language and culture" (item 35, 62.3\%). As for the item 37, "I can plan to teach elements of other subjects using English (cross- curricular teaching, etc.)", less than $50 \%$ (strongly) agreed with it. With regard to other items, $82 \%$ agreed or strongly agreed with that they could "plan specific learning objectives for individual lessons and/or for a period of teaching" (item 32), 67.2\% agreed or strongly agreed with that they could "structure lesson plans and/or plan for periods of teaching in a coherent and varied sequence of content" (item 33), whilst slightly over 50\% (strongly) agreed with that they could "set learning aims and objectives suited to pupils' needs and interests according to curriculum requirements" (item 31). Furthermore, over one third of the student teachers were neutral about three items ( 31,35 and 37$)$, in which one is about student teachers' 
understanding of curriculum requirements and specific pupils, the other two are about the characteristics of teaching language, namely and teaching culture.

Table 2

\section{Student Teachers and Lesson Planning}

\begin{tabular}{|l|c|c|c|c|c|c|c|}
\hline $\begin{array}{l}\text { Questionnaire Section VI } \\
\text { Towards Lesson Planning }\end{array}$ & $\begin{array}{c}\text { Strongly } \\
\text { Agree }\end{array}$ & Agree & Neutral & Disagree & \multicolumn{2}{|c|}{$\begin{array}{c}\text { Strongly } \\
\text { Disagree }\end{array}$} & \multicolumn{2}{|c|}{$\mathrm{N}=61$} & M \\
\hline $\begin{array}{l}\text { 31. I can set learning aims and objectives suited } \\
\text { to my learners' needs and interests according } \\
\text { to curriculum requirements. }\end{array}$ & 9.8 & 41.0 & 39.4 & 9.8 & & 3.51 & 0.81 \\
\hline $\begin{array}{l}\text { 32. I can plan specific learning objectives } \\
\text { for individual lessons and/or for a period } \\
\text { of teaching. }\end{array}$ & 16.4 & 65.6 & 13.1 & 4.9 & & 3.93 & 0.70 \\
\hline $\begin{array}{l}\text { 33. I can structure lesson plans and/or plan } \\
\text { for periods of teaching in a coherent } \\
\text { and varied sequence of content. }\end{array}$ & 16.4 & 50.8 & 26.2 & 6.6 & & 3.77 & 0.80 \\
\hline $\begin{array}{l}\text { 34. I can plan activities to ensure } \\
\text { the interdependence of listening, reading, } \\
\text { writing and speaking. }\end{array}$ & 19.7 & 44.3 & 29.4 & 6.6 & & 3.77 & 0.84 \\
\hline $\begin{array}{l}\text { 35. I can plan activities to emphasise } \\
\text { the interdependence of language and culture. }\end{array}$ & 13.1 & 49.2 & 36.1 & 1.6 & & 3.74 & 0.70 \\
\hline $\begin{array}{l}\text { 36. I can plan activities which link grammar } \\
\text { and vocabulary with communication. }\end{array}$ & 21.3 & 67.2 & 9.9 & 1.6 & & 4.08 & 0.61 \\
\hline $\begin{array}{l}\text { 37. I can plan to teach elements of other subjects } \\
\text { using English (cross-curricular teaching etc.). }\end{array}$ & 11.5 & 36.0 & 42.6 & 6.6 & 3.3 & 3.46 & 0.91 \\
\hline
\end{tabular}

Note: Bold italics indicate that the percentages of neutral and disagreement were together over $50 \%$.

On the student teachers' use of lesson plans and content, over half of the student teachers reported their competency in using lesson plans in practice, such as the necessary adjustments of the sequence of lesson and time schedule. $83.6 \%$ of the student teachers indicated that they could do necessary adjustments of the sequence of lesson as well as $78.7 \%$ indicated that they could flexibly work on the time schedule of the lesson plan in classroom teaching and learning. Also over $70 \%$ indicated that they could teach in light of pupils' knowledge and previous language learning experiences as well as different characteristics of individuals and groups learning.

Language teaching methodology is aimed at creating contexts for communication and maximizing student involvement (Borg, 2006). It appears from the data that over $60 \%$ of the student teachers were competent in 9 out of 10 statements of language teaching methodology. Over $70 \%$ reported that they could select different activities to help pupils to "use different text types (telephone conversations, transactions, speeches, etc.)" and "use new vocabulary in oral and written contexts", as well as select "writing 
activities to consolidate learning (grammar, vocabulary, spelling etc.)" and "grammatical exercises to support learning and encourage oral and written communication". Over $60 \%$ reported that they could select "writing activities to help learners use appropriate language for different text types (letters, stories, reports, etc.)" and "post-listening tasks to provide a bridge between listening and other skills" as well as design or set different activities to practice and develop listening and reading strategies and socio-cultural competence, whilst over $24 \%$ of the student teachers were neutral about them. Concerning item about choosing teaching activities to make pupils aware of the interrelationship between culture and language, slightly over $50 \%$ agreed or strongly agreed with that they were competent in it, whilst 37.7 were neutral.

Over $70 \%$ student teachers reported that they could cater pupils' different learning styles and decide when to use or not use the target language and could use various strategies to facilitate pupils' understanding of the target language, also could encourage pupils to use English in their activities. Over $40 \%$ of the student teachers were neutral or disagreed with that they could plan how to use the target language including meta-language in the classroom.

One third of the student teachers were neutral or (strongly) disagreed with all the items relate to the evaluation and even over $55 \%$ were neutral or disagreed with 2 out of 5 items (table 3). As it shown, over $40 \%$ were neutral about whether they could "select valid assessment procedures appropriate to learning aims and objectives" and "help learners to set personal targets and assess their own performance" whilst the objections were $11.5 \%$ and $21.3 \%$. Other three items which respectively represented their competence in using of in-class activities to monitor and assess pupils' participation and performance, assigning grades for tests and examinations through reliable and transparent procedures, and helping pupils to engage in peer assessment, about $30 \%$ were neutral about the statements, whilst slightly over $50 \%$ agreed or strongly agreed with them. 
Table 3

\section{Student Teachers and Evaluation}

\begin{tabular}{|l|c|c|c|c|c|c|c|}
\hline $\begin{array}{l}\text { Questionnaire Section VI } \\
\text { Towards Evaluation }\end{array}$ & $\begin{array}{c}\text { Strongly } \\
\text { Agree }\end{array}$ & Agree & Neutral & Disagree & $\begin{array}{c}\text { Strongly } \\
\text { Disagree }\end{array}$ & \multicolumn{2}{|c|}{$\mathrm{N}=61$} \\
\hline $\begin{array}{l}\text { 57. I can select valid assessment procedures } \\
\text { (tests, portfolios, self-assessment etc.) } \\
\text { appropriate to learning aims and objectives. }\end{array}$ & 6.6 & 37.7 & 44.2 & 11.5 & & 3.39 & 0.78 \\
\hline $\begin{array}{l}\text { 58. I can use in-class activities to monitor } \\
\text { and assess learners' participation } \\
\text { and performance. }\end{array}$ & 14.8 & 45.9 & 32.7 & 6.6 & & 3.69 & 0.81 \\
\hline $\begin{array}{l}\text { 59. I can assign grades for tests and examinations } \\
\text { using procedures which are reliable } \\
\text { and transparent. }\end{array}$ & 13.2 & 44.3 & 31.1 & 9.8 & 1.6 & 3.57 & 0.90 \\
\hline $\begin{array}{l}\text { 60. I can help learners to set personal targets } \\
\text { and assess their own performance. }\end{array}$ & 8.2 & 24.6 & 45.9 & 21.3 & & 3.20 & 0.87 \\
\hline $\begin{array}{l}\text { 61. I can help learners to engage in peer } \\
\text { assessment. }\end{array}$ & 11.5 & 39.3 & 36.1 & 13.1 & & 3.49 & 0.87 \\
\hline
\end{tabular}

Note: Bold italics indicate that the percentages of neutral and disagreement were together more than or equal to $50 \%$.

Generally, survey results about Czech student teachers' knowledge and skills about implementation of a lesson indicated that student teachers valued each items to various degrees with means on a 5-point scale ranging from a low of 3.46 to a high of 4.15. It appears from the data that Czech student teachers value the using lesson plans and content, followed by the classroom management and the teaching methodology. It is obvious that most student teachers can take into account pupils' interests and needs and their prior language learning as well as different characteristics of individuals and groups learning to use lesson plans and content in a coherent yet flexible way in class. Moreover, most student teachers can cater pupils' needs and different learning styles to take on different roles and to manage individual, partner, group and whole class work. Regarding to target language usage, most student teachers have positive response and consider that they can decide when to use or not use the target language and can use various strategies to facilitate pupils' understanding of the target language, also can encourage pupils to use English in their activities. However, more than $40 \%$ of student teachers indicated that they were not sure or not competent in planning "how to use the target language including meta-language in the classroom". Further, it seems that most student teachers are good at teaching grammar, vocabulary, written and oral communication, and the four skills. As for teaching culture, such as pupils' socio-cultural competence, the relationship between language and culture, etc., more than $30 \%$ of student teachers indicated that they were not sure or not competent in it. 
Concerning lesson planning, a crucial component of teachers' practice, it appears from the data that student teachers are good at planning activities to link grammar and vocabulary with communication and to ensure the interdependence of four skills. Also they can take into account the relationship of culture and language while planning a lesson. Besides, most of them are better at planning specific learning objectives for individual lessons or a period of teaching than structuring plans for lessons or periods of teaching in a coherent and varied sequence of content or setting learning aims and objectives suited to pupils' needs and interests according to curriculum requirements. Actually, only slightly more than $50 \%$ of student teachers indicated that they could set learning aims and objectives in light of specific pupils and curriculum requirements. As for the content of using English to teach other subjects' elements, less than $50 \%$ indicated they could plan it. However, when planning a lesson, teacher's knowledge of language learning theory, teaching methodology and learner activities are as important as knowledge of the individual pupils and curriculum requirements.

Lastly, about evaluation in language teaching, it appears that most student teachers' knowledge and skills need to be improved. For example, most student teachers were not good at selecting valid assessment procedures, such as tests, portfolios, selfassessment etc., and helping pupils' peer- and self-assessment. Even for using reliable and transparent procedures to assign grades for test and examinations, only slightly over $50 \%$ of student teachers indicated that they were competent in it.

\subsection{Discussion}

Based on the presented findings above, Czech student teachers competence in curriculum development could be summarized as: Czech student teachers to a large extent have positive attitudes to specific needs of learning English, followed by different resources, language teachers' different roles, and contexts during uses of curriculum materials. With regard to the implementation of a lesson, they are more confident in the using lesson plans and content, the classroom management and the teaching methodology than in the lesson planning and the evaluation. The survey results showed that only slightly over than $50 \%$ of student teachers reported that they could recommend appropriate books to particular pupils, select materials to stimulate pupil's language skill of writing, and adapt teaching based on specific contextual constraints. Besides, more than $40 \%$ of them indicated that they were unconfident about setting learning aims and objectives in light of specific pupils and curriculum requirements, planning the cross-curriculum teaching using English, etc., selecting texts and activities to make pupils aware of the interrelationship between culture and language, taking into account of different educational stakeholders' expectations and impact of English teaching and learning, as well as the usage of target language in the classroom, and the use of theoretical knowledge in practice. Even for the requirements set in the FEP BE, less than 
$55 \%$ reported that they could understand them, and less than $30 \%$ indicated that they could design language courses around the requirements. As for evaluation in language teaching, it appears from the data that most Czech student teachers' knowledge and skills need to be improved.

In addition, whatever target language usage, results show that lots of Czech student teachers are not competent; it clearly reflects the challenge with language teaching that teachers use language to teach language (Freeman et al., 2009). Another fact appearing from the data seems that Czech student teachers need to be further informed about teaching the relationship between language and culture. It closely matches the views of Byram (2012, p. 83) in that "teachers with many years of experience often say that they do not feel 'qualified' to teach 'culture'.. . This is particularly the case for English... it is not surprising that teachers in preservice training or in the early stages of their career may feel even less confident".

\section{Conclusions}

The primary purpose of this study is to explore what student teachers in general, EFL student teachers in particular, competence in curriculum development is like in the context of the Czech Republic. It has been proved that Czech student teachers need to be further informed of English pedagogical knowledge and curriculum knowledge. To be more concrete, it includes the following knowledge and skills:

- Knowledge and skills to keep the English teaching methodology up-to-date

- The theories of English learning and child development.

- Knowledge and skills of developing and constructing lesson plans, and systematic curriculum design skills (Huizinga et al., 2014)

- Formative and summative evaluation skills

- Knowledge about the current curriculum reform

The study is far from complete. Preservice teachers- students of teaching, unlike students of engineering or law or medicine, they do not approach their professional education feeling unprepared (Feiman-Nemser, 2001). Their personal histories such as elementary and secondary education experiences function as prior knowledge and filter information during preservice teacher preparation (Feiman-Nemser \& Buchmann, 1986). Whether student teachers' preconcepts of curriculum have influence on their competence, as well as whether their gender and teaching practicum experience have the influence, and how teacher education support their competences' development, these questions need further research. 


\section{Acknowledgements}

This paper has been funded by the Palacký University in Olomouc (grant number

PdF_2013_015).

\section{References}

Ben-Peretz, M. (1990). The teacher-curriculum encounter: Freeing teachers from the tyranny of texts. New York: State University of New York Press.

Ben-Peretz, M. (1980). Teachers' role in curriculum development: An alternative approach. Canadian Journal of Education, 5 (2), 52-62.

Beyer, C. J., \& Davis, E. A. (2012). Developing preservice elementary teachers' pedagogical design capacity for reform-based curriculum design. Curriculum Inquiry, 42 (3), 386-413.

Borg, S. (2006). The distinctive characteristics of foreign language teachers. Language Teaching Research, 10 (1), 3-31.

Brown, M. W. (2009). The teacher-tool relationship: Theorizing the design and use of curriculum materials. In J. T. Remillard, B. A. Herbel-Eisenmann, \& G. M. Lloyd (Eds.), Mathematics teachers at work: Connecting curriculum materials and classroom instruction (pp. 17-36). New York: Routledge.

Brown, M. W. (2002). Teaching by design: Understanding the intersection between teacher practice and the design of curricular innovations (Doctoral dissertation, Northwestern University). Retrieved from http://www.inquirium.net/people/matt.html

Byram, M. (2012). Reflecting on teaching "culture" in Foreign language education. In D. Newby (ed.), Insights into the European Portfolio for Student Teachers of Languages (EPOSTL) (pp. 83-98). United Kingdom: Cambridge Scholars Publishing

Campbell, A., \& Luchs, K. S. (1997). Core competency-based strategy. London: Thomson.

Carl, A. (2005). The "voice of the teacher" in curriculum development: A voice crying in the wilderness? South African Journal of Education, 25 (4), 223-228.

Cheung, D., \& Wong, H. N. (2002). Measuring teacher beliefs about alternative curriculum designs. The Curriculum Journal, 13 (2), 225-248.

Connelly, F. M. (1972). The functions of curriculum development. Interchange, 3 (2-3), 161-177.

Černochová, M. (2009). Methods and practices utilized to support teachers' professional development in the Czech Republic. In:The 2AgePro Consortium (Ed.), Methods and practises utilized to support teachers' professional development: Current state description (pp. 2-8). Oulu: University of Oulu, Learning and Research Services.

Darling-Hammond,L., Hightower, A. M., Husbands, J. L., LaFors, J. R., Young, V. M., \& Christopher, C. (2005). Instructional Leadership for Systemic Change: The Story of San Diegos Reform. Lanham, MD: Scarecrow Education Press.

Delamare-Le Deist, F., \& Winterton, J. (2005). What is competence? Human Resource Development International, 8 (1), 27-46.

Doyle, W. (1992). Curriculum and pedagogy. In P. W. Jackson (Ed.), Handbook of research on curriculum (pp. 486-516). New York: Macmillan.

European Commission. (2009). Communication from the Commission to the European Parliament, the Council, the European Economic and social committee and the committee of the regions. Key competences for a changing world. COM. 640 final. Brussels, 25. 11. 2009. 
European Communities. (2008). The European qualifications framework for lifelong learning (EQF). Luxembourg: Office for Official Publications of the European Communities.

European Commission. (2007). Communication from the European Commission to the European Parliament: Improving the quality of teacher education, Brussels, August 2007.

Evans, E. J. (2012). Managing the foreign language classroom: reflection from the preservice field and beyond (Doctoral dissertation, University of lowa). Retrieved from http://ir.uiowa.edu/ etd/2867/

Feiman-Nemser, S. (2001). From preparation to practice: designing a continuum to strengthen and sustain teaching. Teachers College Record, 103 (6), 1013-1055.

Feiman-Nemser, S., \& Buchmann, M. (1986). The first year ofteacher preparation: Transition to pedagogical thniking? Journal of Curriculum Studies, 18 (3), 239-256.

Francesca, C. (2011). Literature review. Teachers' core competences: requriements and development. European Commission. Eudcation and Trainning 2020. Thematic Working Group'Professional Development of Teachers'. Retrieved from http://ec.europa.eu/education/school-education/ doc/competences_en.pdf

Freeman, D., Orzulak, M. \& Morrisey, G. (2009). Assessment in second language teacher education. In A. Burns and J. C. Richards (Eds.) The Cambridge guide to second language teacher education (pp. 77-90). Cambridge: Cambridge University Press.

Green, E. (2008). Curriculum reform in the Czech Republic. The New Presence, (4), 46-48.

Huizinga, T., Handelzalts, A., Niveen, N., \& Voogt, J. M. (2014). Teacher involvement in curriculum design: need for support to enhance teachers' design expertise. Journal of Curriculum Studies, 46 (1), 33-57.

Kirk, D., \& Macdonald, D. (2001). Teacher voice and ownership of curriculum change. Journal of Curriculum Studies, 33 (5), 551-567.

McNeill, K. L. (2009). Teachers' use of curriculum to support students in writing scientific arguments to explain phenomena. Science Education, 93, 233-268.

McNeill, K. L., \& Pimentel, D. S. (2010). Scientific discourse in three urban classrooms: The role of the teacher in engaging high school students in argumentation. Science Education, 94, 203-229.

Mehlmauer-Larcher, B. (2012). The EOPSTL: Promoting language teacher learning in the context of field experiences. In D. Newby (Ed.), Insights into the European Portfolio for Student Teachers of Languages (EPOSTL) (pp. 175-194). United Kingdom: Cambridge Scholars Publishing.

Moreno, J. M. (2005). Learning to teach in the knowledge society. Final report. HDNED, World Bank. Retrieved form http://siteresources.worldbank.org/EDUCATION/Resources/ 278200-1126210664195/1636971-1126210694253/Learning_Teach_Knowledge_Society.pdf

Newby, D., Allan, R., Fenner, A.-B., Jones, B., Komorowska, H., \& Soghikyan, K. (2007). European Portfolio for Student Teachers of Languages: A Reflection Tool for Language Teacher Education. Graz/Strasbourg: Council of Europe Publishing. Retrieved from http://epostl2.ecml.at/

Pinar, W. F., Reynolds, W. M., \& Slattery, P. (1995). Understanding curriculum: an introduction to the study of historical and contemporary curriculum discourses. New York: Peter Lang Publishing, Inc.

Remillard, J. T. (1999). Curriculum materials in mathematics education reform: A framework for examining teachers' curriculum development. Curriculum Inquiry, 29 (3), 315-342.

Seberová, A. (2010). The teacher as researcher and how to develop research knowledge among students-teachers in the Czech Republic. In B. Hudson, P. Zgaga, \& B. Åstrand (Eds.), Advancing quality cultures for teacher education in Europe: Tensions and opportunities (pp. 161-182). Sweden: Umeå School of Education, Umeå University.

Shawer. S. F. (2010). Classroom-level curriculum development: EFL teachers as curriculum-developers, curriculum-makers and curriculum-transmitters. Teaching and Teacher Education, 26, 173-184. 
Shawer, S. F. (2003). Bringing curriculum-in-action to the classroom: A study of teachers' curriculum development approaches and their implications for student and teacher development. Unpublished Ph.D. Dissertation, Faculty of Education, The University of Manchester.

Shulman, L. S. (1987). Knowledge and teaching: Foundations of the new reform. Harvard Educational Review, 57 (1), 1-22.

Snyder, J., Bolin, F., \& Zumwalt, K. (1992). Curriculum implementation. In P. W. Jackson (Ed.), Handbook of research on curriculum (pp. 402-435). New York: Macmillan.

\section{Contact:}

Mgr. LIU Li

doc. PhDr. Jana Poláchová Vaštatková, Ph.D.

Institute of Education and Social Studies

Faculty of Education, Palacký University

Žižkovo nám. 5

77140 Olomouc,

Czech Republic

E-mail: liuli2011cz@gmail.com, jana.polachova@upol.cz 